\title{
AS CHULAS DE RAMIRO COMO FORMA DE RESISTÊNCIA NO ROMANCE MARAJÓ, DE DALCÍDIO JURANDIR
}

\author{
Max Silva do Espírito Santo ${ }^{1}$ \\ Gunter Karl Pressler ${ }^{2}$
}

\begin{abstract}
RESUMO
O artigo analisa a expressão e a função da música regional a "Chula Marajoara", no romance Marajó (1947), de Dalcídio Jurandir. O personagem Ramiro, um vaqueiro que "não tinha emprego certo nas Fazendas", toca as chulas não só para festejar, mas também como forma de resistência frente aos fazendeiros e seus agregados, que servem de tema para a composição das letras das canções do cantor e poeta contra as injustiças. O romance traz como enredo a situação do filho e herdeiro único do Coronel Coutinho, Missunga, que não terminou seus estudos e entra em conflito com seu pai. Durante uma temporada nos campos para acompanhar o embarque de gado, uma das poucas atividades que o fazendeiro se faz presente, conhece bem a vida dos vaqueiros e o Ramiro. Fundamental é o papel da personagem Orminda, "irmã" do Missunga, como companheira temporariamente do Ramiro. Para a análise das personagens, utilizou-se a $5^{\mathrm{a}}$ Edição do romance Marajó, publicada em 2016. No que concerne a interpretação literária, foi feita uma pesquisa bibliográfica sobre a expressão da "chula" na realidade histórica. A análise narratológica se apoia em Wolf Schmid (2014) e sobre o folclore musical em Vicente Salles (1980, 1985, 2005).
\end{abstract}

Palavras-chave: Dalcídio Jurandir. Marajó. Música Regional. Resistência no Campo Rural.

\section{RAMIRO CHULAS AS A FORM OF RESISTANCE IN THE NOVEL MARAJÓ, BY DALCÍDIO JURANDIR}

\begin{abstract}
The article analyzes the expression and function of "Chula Marajoara" regional music, in the novel Marajó (1947), by Dalcídio Jurandir. The character Ramiro, a cowboy who "didn't have a specific job on the farms", plays the chulas not only to celebrate, but also as a form of resistance against the farmers and their associates, who serve as a theme for the composition of the lyrics of the singer's songs and poet against injustices. The novel plots the situation of Colonel Coutinho's son and only heir, Missunga, who has not finished his studies and comes into conflict with his father. During a season in the fields to monitor the loading of cattle, one of the few activities that the farmer is present at, he knows the life of the cowboys and Ramiro very well. Fundamental is the role of the character Orminda, Missunga's "sister", as a temporary companion of Ramiro. For the analysis of the characters, the $5^{\text {th }}$ Edition of the Marajó novel, published in 2016, was used. As far as literary interpretation is concerned, a bibliographical research was carried out on the expression of "chula" in historical reality. The narratology analysis is based on Wolf Schmid (2014) and on musical folklore in Vicente Salles $(1980,1985,2005)$.
\end{abstract}

Keywords: Dalcídio Jurandir. Marajó. Regional Music. Resistance in the Rural Field.

Data de submissão: 29.06 .2021

Data de aprovação: 03.12.2021

\footnotetext{
${ }^{1}$ Mestrando em Linguagens e Saberes na Amazônia da Universidade Federal do Pará - Campus Universitário de Bragança. E-mail: Maxsilva22@yahoo.com.br.

${ }^{2}$ Professor Doutor de Teoria Literária na UFPA. E-mail: gunterkarlpressler@gmail.com.
} 


\section{INTRODUÇÃO}

O romance Marajó publicado, em 1947, pela Editora José Olympio (Rio de Janeiro) recebeu até hoje cinco reedições (1978, 1992, 2008 e 2016). Esta última edição, a $5^{\text {a }}$, de 2016, foi usada, nesse artigo, para o estudo das chulas compostas pela personagem do Ramiro. Para a obra, Dalcídio Jurandir pensou em dois outros títulos "Missunga", o nome da personagem principal da narrativa, e "Marinatambalo"3. O romance recebeu importantes críticas de Moacir Wernek de Castro, Nelson Werneck Sodré, Fausto Cunha e Vicente Salles que apontaram para o regional do romance ("No mundo de Marajó", "Um romance da Amazônia"). Para o nosso estudo visamos o posfácio da segunda edição, "Chão de Dalcídio", de Vicente Salles e seus trabalhos sobre a música e folclore do Pará e Amazônia.

O estudioso enfatiza que "não é possível escrever a história social paraense sem o conhecimento da obra de Dalcídio Jurandir" e enfatiza, particularmente, "o romance 'Dona Silvana', tradição ibérica que se incorporou ao folclore brasileiro" (1998, p. 368; ressalva no original) e a situação dos negros no Pará. O tema da "D. Silvana brota espontaneamente no papel de Orminda, É denunciado logo no segundo capítulo, quando Missunga interrogativamente revela a situação inicial e um dos seus conflitos internos: "Orminda, filha da negra Felismina, sua ama-de-leite, pode ser sua irmã". Ela tem, no decorrer da história, um papel importante ao lado de Ramiro, "poeta do povo, cantador e compositor de Chulas, havia de cantar uma chula falando dessa Mulher", salienta Salles, "mundiadeira de homens, contando mortes na sua história, com marca de faca no rosto"” (1978, p. 372-373).

O personagem Ramiro, vaqueiro que "não tinha emprego certo nas Fazendas" (JURANDIR, 2016, p. 103), aprendeu cedo tocar o violão e nas suas composições e execução das chulas se manifestam tanto a vida cotidiana nos campos quanto a forma de resistência frente aos fazendeiros e seus agregados, além de outras formas de injustiça que servem de tema para a composição das letras das canções. Ramiro aparece pela primeira vez no romance no capítulo 29 (o romance é dividido em 53 capítulos), depois das desventuras fracassadas do Missunga, no momento em que pai e filho viajam para as fazendas mais de dois, três dias de distância da Casa Grande e do vilarejo Ponta de Pedras.

\footnotetext{
Coronel Coutinho mandou abalar a malhada. Os vaqueiros sacudiram as cordas, lambaram os cavalos, ergueram as rédeas:

— Ei! Ei! Ei! Vera! Ei! boiama!

Reses bravias levantaram as cabeças, farejando o ar espesso de pó. Os touros armavam a fuga, estonteados sob a poeira tresmalhando.

— Faz logo a esteira! Rápido isso! (Ibid. p. 189).
}

Desta forma, in medias res, os capítulos 29, 30, 32, 33 e 35 apresentam os acontecimentos nos campos da Ilha de Marajó, o trabalho de apartação do gado no campo tanto para ferra, para a contagem ou para embarque, a relação de Missunga com os vaqueiros e o reencontro com Orminda.

\section{CORONEL COUTINHO E SEU FILHO MISSUNGA}

O personagem central é Missunga, filho do Coronel Coutinho, proprietário de "cinqüenta ou oitenta fazendas" (JURANDIR, 2016, p. 210). Coutinho é primo do Capitão

\footnotetext{
${ }^{3}$ Marinatambalo foi o primeiro título atribuído ao romance conhecido hoje como Marajó. O termo, que era empregado como um dos nomes da Ilha do Marajó, segundo Dalcídio Jurandir (1942), era apenas um entre tantos outros "belos e estranhos": Camamoro, Paricura e Ilha Grande de Joanes. Ainda segundo o escritor "Os índios e espanhóis tinham agrado em chamar a ilha por um nome que enchia a boca: Marinatambalo" (JURANDIR, 1942, p. 325).
} 
Guilherme e do Velho Nelson, proprietários de terras em menor proporção. A história começa com o fracasso individual do Missunga, caçador ("As tocas desertas, os ocos de pau vazios. Detinha-se, vencido, diante do mato virgem", Ibid. 2016, p. 11) e, como se percebe no decorrer da história, o fracasso do filho rebelde em querer realizar um sonho de um menino rico brincando de dono da terra (Colônia Felicidade). Somente depois da morte (não) esperada do pai, o filho assume - pressionado pelas circunstâncias e seguindo sua predisposição interna - a herança e toma decisões da sua classe social e racial.

Desde o início, o romance apresenta o conflito entre pai e filho, que discordam quase sempre um com o outro, por conta, principalmente, do fracasso escolar do rapaz, que morara em Belém com intuito de formar-se em Direito para ter o desejado diploma. No entanto, o jovem se mostra sem vontade para o estudo. O pai insiste que ele volte para estudar, pois tem o sonho de vê-lo formado para assumir a herança, os negócios da família com mais capacidade e seguir também a carreira política; coisas que o rapaz, a cada vez, se mostra menos interessado. Algo se deve notar é que pai e filho, nitidamente, além de representarem gerações diferentes, apresentam visões ideológicas diferentes. O pai mantém-se conservador, e o filho, apesar do permanente fracasso, deseja modernizar os negócios da família e a situação dos habitantes no vilarejo e nas beiradas dos rios, no contorno e nas fazendas.

Há, ainda, o conflito interno que o rapaz apresenta entre três amores, duas caboclas, Alaíde e Guita, e sua provável irmã Orminda. O pai, obviamente, não concorda com os relacionamentos e insiste que o filho volte para Belém, porque a vila não é lugar para ele. Ressaltando, então, a questão de que fazendeiro casa os filhos com filhos de fazendeiros, pois a ideia é sempre aumentar o gado, as terras, as posses e não dividir, de modo que um relacionamento com uma cabocla poria em risco a estrutura social vigente.

$\mathrm{Na}$ ausência do pai, Missunga implanta a colônia agrícola "Felicidade" nas terras do parente seu Felipe, que acabara de morrer. Missunga está junto com Alaíde, a qual acaba tomando à frente da parte organizacional para que o empreendimento dê certo, pois o filho fazendeiro, em meio a devaneios e desilusões, se mostra incapaz de dar prosseguimento de uma ideia surgida na sua cabeça; uma incapacidade estrutural, pois já tinha colecionado outros fracassos além da escola: uma roça, um canavial e um engenho não deram certo sob sua responsabilidade. Depois de poucas semanas, a situação da colônia se torna insustentável e o Coronel, voltando da sua cura de Minas Gerais, termina este "empreendimento" e vende as terras à uma companhia de japoneses ${ }^{4}$.

O relacionamento com Guíta, a filha do Mestre Amâncio, que apronta um novo barco para o Coronel, se intensificou paralelamente da relação com Alaíde, até quer conversar com seu pai sobre o casamento com ela: "- Sabe pai, cansei-me de procurar uma noiva em nosso meio [...] Quero agora uma mulher simples ao meu lado [..] Guíta até ontem era uma menina. Vem de meu tempo, brincamos juntos, era quem mamãe mais gostava em Paricatuba. Lembra-se? Afinal queria uma criatura simples, que não me chateasse, uma companheira...". Não falou, mas queria falar, ou melhor, "achava bom dizer: esta é minha companheira" (Ibid. 2016, p. 185). O "discurso vivenciado do narrador na perspectiva figural" (SCHMID, 2014, p. 121-141, 181-192) mostra o caráter do Missunga e suas dúvidas diante do élan vital do seu pai, que desarma o filho, virando a metáfora do amor e, desta forma com uma resposta do "seu meio" confirma aquilo que o próprio filho já sentia, "reestabelecendo nele [Missunga] o Coutinho por inteiro". Assim, na lancha, "com o pai, a caminho das fazendas", Missunga se distancia da Guíta e dos seus sonhos e entra na vida prática das fazendas, também porque ele gosta da vida nos campos. Gosta de estar com os vaqueiros e os vaqueiros gostam dele. Sabese que empreende as caçadas, mesmo não tendo muita sorte e pouco conhecimento das atividades da fazenda, é uma atividade do povo nos campos.

${ }^{4}$ A referência da venda das terras do seu Filipe indica o fato histórico da imigração japonesa no Estado do Pará, em 1929. 
Campos do seu pai; a grande propriedade ao longo da ilha, cercas de arame, currais, lagos, malhadas, Chaves, Anajás, Soure, Cachoeira [...] De setembro a janeiro, povo de Cachoeira, Anajás, Baixo Arari, Soure, Ponta de Pedras, arma barracas nas margens do Arari e do lago. São as feitorias. Missunga prepara-se para assistir a tarrafeação, a lanceação, o encontro do peixe no rio. Contam-lhe que os pescadores do lugar não gostam muito daquele povo de arribação (JURANDIR, 2016, 191, 194).

Neste momento, novos personagens surgem, em particular os vaqueiros Gaçaba e Ramiro. Orminda reaparece depois do fracasso de Felicidade e outras desventuras (parece que é a parte mais extrema e mais perdida do "irmão"); a esta altura, é companheira de Ramiro. Orminda também está ligada a pajé Nhá Leonardina, conhecida como a flor dos pajés do Arari, a quem o Coronel respeita e teme.

\section{RAMIRO}

Ramiro, o vaqueiro e "campeão dos violinistas do Arari” (Ibid. 2016, p, 191), é inserido no enredo do romance no capítulo 29 e sai no capítulo 51. Missunga, quem o chama assim, quando do retorno de uma outra fazendo, deixa claro o quão específico é o papel do vaqueiro. Missunga não o chama de "grande", como chamou a Gaçaba ("de vara e ferrão, choutando na sua égua alvaçoa, o Gaçaba" $)$. Missunga chama o vaqueiro de "campeão", ou seja, não há outro melhor naquela função. Ramiro está no topo, em cima, é o campeão. Ramiro, cujo nome "tem origem no espanhol Ramirus, uma forma latinizada de Ranimir, um nome visigótico formado pela união dos elementos germânicos ragin, que significa 'conselho' e mari, que quer dizer "famoso, ilustre", . Sendo assim, o conselheiro ilustre, "campeão dos violinistas" é a personagem responsável para tornar as noites dos vaqueiros e pescadores das feitorias menos pesada com suas músicas, depois de um dia duro de trabalho, e aconselhar para superar as dificuldades.

Missunga "[r]gressava para ouvir Ramiro, o tocador de chula havia de tornar, com efeito, menos pesada àquela noite"; a noite na fazenda Diamantina quando pensava muito em Alaíde. "- Como vai esse campeão dos violinistas do Arari?/ Ramiro soltou sua lenta e grossa gargalhada, deitou o violino no braço para executar a música. Tocava de orelha" (Ibid.). No caso dos instrumentos de Ramiro, pode-se depreender que tais instrumentos estavam sempre na parede. Mas, o vaqueiro já não tinha mais família. Na parede, já não havia mais nada, restava apenas seus instrumentos. Na vida do poeta cantador de chula seus instrumentos eram tudo, sua família se tornou o mundo.

\footnotetext{
5 JURANDIR, 2016, p. 189. Faz jus salientar que no trabalho de apartação do gado no campo tanto para ferra, contagem ou para embarque, o trabalho do guia é feito montando um animal macho. Gaçaba, contudo, montado numa égua alvaçoa, que significa a mudança na cor da pelagem de um novilho, a partir da castração deste animal. Então, todo animal macho ao ser castrado sofre um processo de modificação na tonalidade de sua pelagem. Entende-se que, neste caso, o processo de castração é substituído por sua entrada na fase de acasalamento, por isso a alteração em sua pelagem. $\mathrm{O}$ animal montado pelo vaqueiro é um animal jovem, na flor da idade, força e velocidade. Atributos necessários para o bom desenvolvimento do trabalho.

${ }^{6} \mathrm{https}$ ://www.dicionariodenomesproprios.com.br/ramires; acesso 12/03/2021. Esta entrada do cantor e vaqueiro lembra muito ao discurso do Sócrates sobre a alma alado (os cavalos e o cocheiro) e o mito das cigarras que eram "homens, dos que existiam antes de nascerem as Musas [...] A mais venerada, Calíope, e a que vem depois dela, Urânia, os que elas anunciam são aqueles que passam a vida filosofar e que honram a música das duas [...] pois são elas que, sendo sobre o céu e os discursos divinos e humanos, emitem a mais bela voz" (PLATÃO, 2016 [-370], p. 119). E a continuação do trecho ("Muitos portanto são os motivos para conversar e não adormecer ao meio-dia"), pode-se compreender tanto no próprio diálogo Fedro sobre a retórica como no romance de Dalcídio, pois o "lacônico" de Platão, aquele habitante de Sparta, é o romancista que declara: "não existe arte retórica propriamente dita sem o conhecimento da verdade, nem jamais haverá tal coisa" (PLATÃO, 2001, p. 99).
} 
Dalcídio Jurandir descreve a situação dos habitantes dos vilarejos, dos rios e dos campos; mostra e caracteriza as várias formas de resistência frente aos fazendeiros e agregados. Não existe Literatura sem conhecer a verdade. Muitas vezes, a desestruturação da família pelas doenças, pela perda de trabalho e pela expulsão dos sítios é a razão, o motivo ou a última saída à vacância e sua forma de resistir e lutar. $\mathrm{O}$ vaqueiro perdeu a família. A mulher, Isabel, morreu três dias depois de ter sido picada por uma cobra jararaca. "Depois os dois filhos comidos pelos vermes e pela febre na beira do Anajás" (JURANDIR, 2016, p. 192), o vaqueiro, de retorno do enterro do segundo filho e, "uma tarde, olhou o que havia dentro de sua mala e os tarecos da barraca. Na parede restava o violão, uma viola sem corda, o saco do violino, as perneiras de couro cru. Desarmou a rede, largou pros centros, sua família era o mundo" (Ibid.).

Vale discorrer sobre o verbo "restava" utilizado pelo narrador no trecho acima. O verbo está no pretérito imperfeito. $\mathrm{O}$ verbo, nesse modo verbal, tanto no português como em francês, significa ação passada, mas que continua no momento que está sendo falada. Dá ideia de que aquilo era hábito, uma ação contínua e, de certa forma, passiva e frustrada. De outro modo, identifica o narrar do romancista Dalcídio, que emprega diversos tempos na narrativa. A variedade de tempos gramaticais, o mais-que-perfeito, o pretérito imperfeito e o pretérito perfeito, articulam no discurso do narrador e o fundo do texto da personagem. Pelo discurso vivenciado no pretérito imperfeito, discurso indireto livre, se sabe dos fatos internos das personagens.

Ramiro não tinha emprego certo nas fazendas. Quando a necessidade era muita, a ponto de não ter mais uma camisa curta, ia ajudar os seleiros. Tido como bom curtidor, armando bem um celim. Sangrava bois velhos pras matalotagens do Coronel Coutinho. (Ibid.).

Emprego já não tinha mais. Então o vaqueiro "gostava de se vingar dos fazendeiros ruins - boas vacas gordas esfaqueava nos encobertos. Não era ladrão de gado, não tinha sangue para essa aventura, se vingava, dizia ele, do tempo em que era feitor mal pago e das vezes em que sua mulher, ainda viva nesse tempo, tinha que reagir contra o desrespeito dos patrões. (Ibid.). O ato de vingar-se que o narrador, utilizando-se de um discurso indireto, apresenta e reflete a forma que o vaqueiro encontra para resistir aos abusos dos patrões. Vigava-se por seu trabalho desvalorizado e vingava-se pela honra de sua companheira. Ao esfaquear uma "boa vaca gorda", vale lembrar que a aventura do Ramiro era frequente, já que a descrição das vacas aparece no plural, o que indica que mais de uma vaca fora sangrada por ele e, deve-se entender, que não foi na mesma ocasião. $\mathrm{O}$ ato de esfaquear não era segredo, pois na alimentação dos vaqueiros e suas famílias faltava, particularmente, a carne. $\mathrm{O}$ narrador faz com que se compreenda que o próprio Ramiro contava suas façanhas aos demais, quando fala: "dizia ele", colocado entre vírgula no discurso. O narrador abre espaço para que a personagem fale.

Para Giovanni Gallo (1981, p. 73), padre e recém-chegado na comunidade Jenipapo, próximo do Lago do Arari, três décadas depois do tempo do romance, publicou depoimentos nos jornais de Belém para falar da miséria na Ilha de Marajó, da situação dos vaqueiros e suas famílias. Existem dois tipos de "ladrão", esclarece Gallo: "o amador e o profissional, em pequena ou larga escala, coadjuvante por um perfeito serviço logístico de informação, venda e cobertura a todo nível" (Ibid.). Pode ser que "alguém que foi atrás de uma capivara ou de um jacaré [...] encontra uma boa oportunidade, aproveita". Atrás do outro já está "uma turminha [...] O organizador do roubo [o profissional], quem financia e faz o papel de receptor, fornece canoa, espingarda, machado, sal, cachaça e maconha" (Ibid. 1981, p. 74; precisa de sal, pois o transporte da carne é demorado). De qualquer forma, o narrador ao dizer que Ramiro "não era ladrão de gado, não tinha sangue para essa aventura" indica que o vaqueiro está correto em 
suas conclusões. "Capitão Guilherme chegou a ser turuna na política, no roubo de gado e de terras. Sempre questionando com os fazendeiros vizinhos, sobretudo com o primo. Seu maior desejo: o Arari inteiro na sua mão" (JURANDIR, 2016, p. 225).

Capitão Guilherme era bastante conhecido nos campos por ser patrão ruim; o que se podia fazer para se dar bem era ter estratégia: "Gaçaba combinava com os vaqueiros: O coirão velho nos paga. Quebra, sem pena. Uma rês quebrada é rês sangrada, é matalotagem forçada, e Gaçaba ria" (Ibid. 2016, p. 226). O ato de Ramiro não se encaixa em nenhuma das duas possibilidades trazidas por Gallo (1981); ele não é nem amador nem profissional. Ele, como os outros vaqueiros, se vingou desta forma, pois o Capitão Guilherme na "sua lancha e barcos os tripulantes comiam peixe podre ou ardido. Só peixe seco o rancho nas fazendas. Num tempo de crise de farinha, Primo Guilherme fornece aos vaqueiros farelo de arroz. Perguntaram-lhe então:

- Mas, Capitão, como os vaqueiros podiam comer farelo de arroz em vez de farinha?

Capitão Guilherme esfregou as mãos e ajeitou o punho da camisa:

- Ora, podia ser... Tudo pode acontecer no mundo [...]

Capitão Guilherme criava porcos de meia com os vaqueiros. Numa fazenda dele lá pros centros, levou seus empregados para os duros trabalhos mastigando em seco, o dia inteiro. Pela boca da noite, voltaram, esfalfados e famintos. Na escada da casa grande, Capitão Guilherme desabotoando a camiseta, voltou-se para os seus empregados:

- Agora pessoal, vamos ver se a gente faz uma pescariazinha no lago pra arrumar a janta...

Tinha mais de quinze mil reses, mil e cem contos no banco e uma crescente renda de prédios em Belém (JURANDIR, 2016, p. 225).

Esta história, Ramiro contava a sua companheira Orminda. E, desta forma, o Gaçaba combinou com os vaqueiros: "Quebra, sem pena". E o Capitão sabia desta forma de se vingar, mas não pode fazer nada: "Capitão Guilherme, gorducho e vermelho, largou todas as suas obscenidades contra os vaqueiros. Mais uma novilha quebrada!/- Suspendo o serviço. Meto eles todos no xadrez!/Carnes sangrentas chiavam no braseiro, os homens comiam filé com pirão de leite" (Ibid. p. 226).

Não dá para negar que o carro chefe da resistência e da alegria demonstrado por Ramiro são as letras de suas chulas. Ademais, como estratégia narrativa, Dalcídio insere Orminda para fazer par com o vaqueiro. Ela seria, a nosso ver, a conselheira particular do conselheiro ilustre. "À noite, Ramiro tocou e cantou para Orminda” (Ibid. p. 227).

\section{CHULA MARAJOARA E RESISTÊNCIA}

Ramiro, "o tocador de chula", é quem entretém os trabalhadores dos campos.

Gaçaba dizia que ele tinha a mão curada para tirar tudo que queria dos instrumentos. - Viola com ele diz por que geme ou diz por que não geme.

Gaçaba, velho companheiro de serenatas nas margens do Arari, trouxe a garrafa de cachaça que Missunga mandara buscar. Ficaram no pátio da casa da fazenda, esperando a lua nascer quando então a festa começaria. Ramiro fechava os olhos ao tocar o violino. Depois do violino, solou violão, e inventava chulas, as chulas corriam os campos, batiam bem fundo no coração do povo. Cantou a chula do Raimundo Sérgio que, para chamar a namorada, imitava o mugido da vaca na porteira do curral. Os vaqueiros em torno, fedendo a sela e a cavalo, bebiam atentos e risonhos (Ibid. p. 191-192). 
Ramiro é o tipo de vaqueiro, por ser "curado", como diz o amigo, aprende a tocar os vários instrumentos que utiliza com uma propensão nata, como bem aponta Feio Junior (2004, p. 160):

O vaqueiro do Marajó não vivia somente do dia a dia das fazendas, dos feitos extraordinários, dos acontecimentos fora do comum [...] mas também de uma boa dose de humor, poesia e música.

Na música aperfeiçoava-se na execução de instrumentos como violino, violão, viola, por simples intuição, propensão nata, força de vontade e inteligência, sem professor e sem método, mas o suficiente para darem vasão (sic) a seus sentimentos, prazer de ouvir a si próprios e oferecer aos seus ouvintes mais uma de suas habilidades.

O narrador apresenta e descreve a forma como as chulas do Ramiro surgem e são recebidas pelo povo. O vaqueiro, como constata Feio Junior (2004), não tem professor. Esse tipo de fato é extremamente frequente nos campos "inventava chula, as chulas corriam os campos, batiam fundo no coração do povo". (JURANDIR, 2016, p, 192) O bater fundo no coração é que assusta os fazendeiros e seus agregados como Manuel Raimundo, o administrador poderoso do Coronel Coutinho.

Vicente Salles (2007) aponta que as chulas surgem como um tipo de dança e gênero de canção popular de origem portuguesa. Além disso, aponta o autor, a chula está presente em diversas regiões do país. No Marajó, no entanto, ganha, ainda, outra conotação. Devemos, naturalmente, considerar que as composições das chulas marajoaras são repletas de temas que giram em torno do cotidiano dos vaqueiros. Prova disto é a composição "Morena" (1930), de Waldemar Henrique (Deixei cabana / Deixei meu gado /Pra ver morena /Do meu cuidado / Morena bela / Que tanto amei / A fé mais pura / Eu te jurei) dos feitos destes no trato com o gado, visagens e assombrações (a chula do Ramiro sobre a vaca branca do lago Guajará), acima de tudo, as chulas servem para que o compositor fale, de forma clara, com seus pares, sobre o modo como são tratados por seus patrões.

Salles (2017), assim como Feio Junior (2014), ressalta a predominância de cantadores de chulas por todo lugar da Região dos Campos do Marajó. Vale lembrar que a chula está muito presente em solo marajoara por ser aqui o lugar onde se concentrou um número considerável de negros escravos e, inicialmente, o gênero surge em forma de devoção aos santos. Principalmente são Benedito e Nossa Senhora do Rosário.

Ademais, as chulas foram criadas por mulheres negras como forma de "agradar" a igreja católica que se mostrava bastante incomodada com o lundu. A chula é comumente chamada de Taieiras ou Talheiras, nome derivado das talhas que eram usadas para que as negras transportassem água do rio até a casa de seus senhores, momento em que cantavam e dançavam.

No romance Marajó, contudo, as chulas representam mais que um simples culto aos santos ou a forma de diversão e alento para aliviar um dia duro de trabalho. As chulas compostas por Ramiro representam a voz e o grito daqueles que são, constantemente, silenciados pelos grandes proprietários de terras. Representam sua cultura e identidade, herdadas da ancestralidade dos primeiros negros que pisaram o solo marajoara, miscigenados, à posteriori, com os indígenas que aqui habitavam.

Nos versos [...] surpreendem-se vozes de filhos das Áfricas [...] Dalcídio recupera a negra Sabina, contadora de histórias do universo mítico-lendário [...] traz ainda imaginário local e a pressão vivida por populações amazônicas para escrever suas tradições e sabedorias pelos códigos do mundo ocidental letrado. Nos romances e contos de Helena Tocantins também emergem negros da fazenda de seu pai, produtores, cantadores e tocadores de chulas. Homens e mulheres, filhos das diásporas africanas que suplantados em terras marajoaras disseminaram formas de 
artes e estéticas de vida diversas e se apropriaram daquelas compartilhadas por suas alteridades. (PACHECO, 2012, p. 209)

Bruno Nettl (2006 p. 14) ao abordar Kartomi (1981) indica que o estudo deste autor "apresenta um conjunto de maneiras segundo as quais as sociedades mudaram suas músicas em resposta a transformações culturais". Se as sociedades mudam suas músicas de acordo com as transformações culturais, não se pode negar que música e cultura estão imbricadas e em permanente relação em que uma tanto depende quanto necessita da outra para transformarse e se adaptam à realidade, portanto.

Ainda neste viés de adaptação, percebemos que, de fato, as temáticas que envolvem as letras das chulas marajoaras, segundo Feio Junior (2014), retratam o cotidiano dos campos. Nesta mesma direção, vimos acima, aponta Pacheco (2012), ao referir-se às histórias de negra Sabina. Em Marajó, de Dalcídio Jurandir, as letras das chulas do Ramiro que surgem incialmente na trama pouco se mostram como forma de resistir aos abusos sofridos. No entanto, após a perda de tudo, o vaqueiro se adapta à sua nova realidade e, em companhia de Orminda, o leitor começa a perceber um engajamento maior da personagem em questões mais sociais do seu povo. As letras passam a servir como alerta aos demais vaqueiros e agregados e como resistência à violência dos fazendeiros.

Henrik Aubert (2007, p. 299) ao referir-se a "uma antropologia da música", discutida por Seeger (1987b) afirma que este estudo da antropologia enxerga a forma musical como sendo parte da cultura e da vida social. (SEEGER, 1987b, p. xiv apud EDUARDO HENRIK AUBERT, 2007, p. 299). Por isso, dissemos acima, que a música guarda relação muito próxima com a cultura e, graças a isto, com a vida social das pessoas. Este fato é perfeitamente visível nas chulas compostas por Ramiro, porque as chulas, além do viés social, compõem também a identidade dessa gente do campo.

Rodrigo Campos (2012), trazido por Mariana Andrade Gomes (2014, p, 206) diz que, como compositor, cria sua identidade através do "contar histórias, falar de personagens". É justamente isso que faz Ramiro. Através de suas chulas ele também conta histórias e não esconde os personagens dos quais trata nas canções. Para Campos (2012) é isso que caracteriza o cantor, "dá estilo e identidade."

No seu estudo, Wolf Schmid (2014, p. 207) se refere ao Formalista Russo Vladimir Shklovsky que afirma "que o processo de percepção é um fim em si mesmo na arte e deve ser prolongado em conformidade. Os objetos de percepção eram os próprios atos complicadores de formação, como Shklovsky colocou - 'dançar atrás do arado' ou o 'fazer de uma coisa"”. "A dança também é uma forma de caminhar, que é sentida; mais precisamente, um passeio que é configurado de uma tal maneira que se sente. E assim, dançamos atrás do arado; acontece porque estamos arando, mas não precisamos do campo arado" (SHKLOVSKY 1919a, 36). "Porque estamos arando" significa "porque gostamos da sensação de arar".

Schmid resume o assunto sobre o conceito da "formação", levantado por Roman Jakobson (1921), que aponta para a experiência de trabalho que é transformada em dança e canto, quer dizer, em cultura de identificação de trabalho, de sofrimento e de alegria. Em relação à vida do ribeirinho, ou como diz Herculano Inglês de Sousa: "O caboclo não ri, sorri apenas; e a sua natureza contemplativa revela-se no olhar fixo e vago em que se leem os devaneios íntimos, nascidos da sujeição da inteligência ao mundo objetivo, e dele assoberbada. Os seus pensamentos não se manifestam em palavras por lhes faltar, a esses pobres tapuios, a expressão comunicativa, atrofia pelo silêncio forçado da solidão" (2005 [1893], p. 31).

O silêncio que a esses caboclos dos campos marajoaras sempre é imputado, lhes resta a saída de cantar. Usar a música para que sua voz possa ser ouvida. Música e resistência ou a música como forma de resistir e denunciar alcança um patamar elevado a partir, principalmente, de 1964, no Brasil, ano que começou o regime repressivo da Ditadura Militar. 
No romance Marajó, curtas passagens fazem referência a esse período da história brasileira: "Fique certo de uma coisa, meu caro, só uma ditadura militar é que pode endireitar este país. Só uma ditadura militar" (JURANDIR, 2016, p, 196).

O vaqueiro Ramiro, talvez pela veia política de seu criador, Dalcídio Jurandir, representa nas fazendas essa voz que resiste aos abusos dos patrões.

A música para a maioria das pessoas é uma forma de expressar sentimentos, desejos, frustrações, conceito que não está muito longe da realidade, pois durante muito tempo a música foi utilizada como forma de "abrir os olhos da humanidade" para as questões que afligiam o mundo, como a guerra, a discriminação, a opressão, etc. (PERCÍLIA, BRASIL ESCOLA, 2021)

Percília (2021) diz ainda que "Para muitos músicos, a canção não deve falar de coisas banais, mas sim, explorar letras na tentativa de mudar a realidade cruel em que grande parte do mundo vive, é buscar através da música a liberdade para a humanidade" (grifos nossos). Ramiro, no entanto, buscava mudar seu mundo através de suas chulas que tocavam fundo no peito dos caboclos. Nomes brasileiros importantes servem como referência brasileira como poetas que sofreram a repressão do Regime Militar, e buscavam através da música, além da crítica ao governo, chamar o povo para a luta. São eles: Gilberto Gil, Caetano Veloso, Chico Buarque, Geraldo Vandré, entre outros.

$\mathrm{Na}$ ficção dalcidiana, portanto, é Ramiro quem tem o papel de chamar o povo para a luta com as letras de suas chulas que falam dos podres dos patrões, dos acontecimentos cotidianos da lida nas fazendas, dos fatos extraordinários dos vaqueiros, conforme apontou Feio Junior (2004).

\section{ORMINDA}

Orminda chega ao Lago do Arari depois de uma série de acontecimentos. Ela saíra da casa de sua mãe, depois de participar de uma sessão espírita na casa de Manuel Rodrigues. Lá, houve confusão, envergonhada, ela fora buscar abrigo com Capitão Lafaiete. Quando Missunga instalou Felicidade, Orminda foi para lá junto com o irmão Marcelino e Tenório que tinha perdido seu sítio. Durante uma festa, Orminda rejeitou o convite para dança de um cearense macho, que se sentiu ofendido, e lhe marcou o rosto e o braço com uma faca. $\mathrm{O}$ irmão entrou para defendê-la e foi morto pelo agressor da Orminda. Em seguida, o remeiro Benedito que tinha se preparado para dançar com Orminda, chegou e matou o cearense.

A colônia Felicidade foi desfeita pelo Coronel e Orminda foi para outras localidades ("Orminda, o braço ferido, o rosto cortado, embarcava numa canoa que a própria Alaíde ignorava de onde viera nem para onde partia" (JURANDIR, 2016, p. 151) e, depois por recomendação, veio para se tratar com a pajé Nhá Leonardina, "teve vontade de lhe dizer: Tome conta de minha vida" (Ibid. p. 202). A pajé tratou ela. "Sentia-se bem agasalhada na barraca de Leonardina, a flor dos pajés dos campos e dos lagos do Arari. Queria ser sua afilhada [...] - Agora que tu vai fazer danação por esta beirada é o que eu sei/Orminda fez uma careta e a velha gracejou: Ramiro havia de cantar uma chula nos ranchos e no toldo das geleiras, falando de uma mulher de Marajó-Açu, mundiadeira de homens, contando mortes na sua história, com marca de faca no rosto" (Ibid. p. 203-204).

Então, Ramiro já conhecido naqueles campos, Orminda o conhece sua história com a pajé:

- Me emendei de uma vez pra sempre, e só fiquei bom mesmo depois que ela me fumentou, me tratou.

Orminda fitou Ramiro que sorriu e se curvou a fim de abrir a barriga do peixe para ela. O clarão das brasas lhe mostrava a cara de um verdadeiro caboclo já maduro, queimada e larga, o bigode ralo. 
- Você agora deve ter o corpo fechado pela Madrinha, não?” (JURANDIR, 2016, p. 208).

Mantém um relacionamento por determinado período, pode-se dizer que dura um verão. Neste primeiro momento do relacionamento, os dois seguem juntos pelos próximos três capítulos. Dissemos no início que julgamos Orminda a conselheira do "conselheiro" Ramiro, porque é ela quem demanda que o companheiro componha as chulas com teor de resistência: "Os dois subiram a beirada, Orminda, então, pediu a Ramiro: - Me faz então uma chula assim: quem merece o castigo de ferro em brasa? É o meu pedido. Ofende?" (Ibid. p, 224). Antes, soubera da história do Gervásio, contada por Ramiro. Gervásio foi acusado de ter roubado uma vaca muito estimada por Coronel Coutinho, ainda novo. Coronel, então, marcou Gervásio com ferro em brasa para que todos soubessem que era ladrão. Ramiro quando soube, pensou em compor uma chula: "castigo de ladrão é ferro em brasa" (Ibid. p. 223). Declinou depois de conhecer Gervásio, pois, para ele, não tinha jeito de ladrão: "Gostava de Gervásio." (Ibid.); contou à Orminda que enquanto Coronel ferrava o vaqueiro, "assinalava gado alheio, tomava conta das fazendas nacionais, botava criadores pequenos na miséria" (Ibid.). Daí a ideia de compor a chula não contra o vaqueiro, mas contra o fazendeiro. A nova chula do Ramiro:

Dias depois, os vaqueiros da beirada, os pescadores no toldo das geleiras, as
lavadeiras, conheciam a chula nova de Ramiro. Por isso Manuel Raimundo o
expulsou das fazendas. A notícia correu. As festas iam perder o sal, aquela animação
que só Ramiro sabia dar. Manuel Raimundo por medo, dizia Gaçaba, não queria
Ramiro nas fazendas do Coronel Coutinho. Medo da língua e da música de Ramiro,
seus instrumentos lhe davam aquela liberdade, aquela cadência, aquela franqueza
que os brancos temiam. (Ibid.).

Gaçaba, muito amigo de Ramiro, explica a função dos instrumentos e a liberdade que tais instrumentos possibilitam ao poeta, pois, Ramiro, pela música, falava com "aquela franqueza que os brancos temiam" e o melhor era que as músicas falavam a língua dos campos, compreendida por todos, sobretudo pelos "vaqueiros da beirada, os pescadores no toldo das geleiras, as lavadeiras". Além disso, as chulas de Ramiro eram com temáticas do cotidiano: "As chulas de Ramiro falavam dos vaqueiros, visagens, assombrações, podres dos brancos, davam vida" (Ibid. grifos nossos).

Gaçaba via nos olhos de Ramiro o juramento de que havia de fazer uma chula contra Manuel Raimundo [...] Então Ramiro esperou mais uns dias em Santa Cruz, no lago, e olhando tantas vezes para Orminda, desfiando aqueles cabelos, dormindo naquele colo, curando o baque da perna naquelas mãos, principiou a chula contra Manuel Raimundo.

Uma noite, Missunga ouviu Orminda cantando a chula entre as mulheres da beirada do lago que salgavam taumatás (Ibid. p. 224).

Como sempre, desde que estão juntos, Orminda serve de inspiração para as composições das chulas com teor político do companheiro. Desta vez, por conta da expulsão que sofrera, compôs contra Manuel Raimundo. Gaçaba pede que o amigo, já expulso das terras de Coronel Coutinho, permaneça pelas terras do primo Guilherme, desafeto do Coronel. O narrador na perspectiva figural indica que a companheira irá com ele: "Adeus, Orminda, na certa irá com ele, ei mulherão de cabelo na costa, na garupa do cavalo cardão" (Ibid.). Gaçaba indica também a cor do animal: Cardão, ou seja, branca. A cor da montaria do Ramiro, até antes de seu retorno ao rio Abaí será branca. Assim, permanece pelo tempo em que os dois, ele e Orminda, estiverem juntos. Mesmo depois que Orminda o deixou, muito vivas ficaram as lembranças com ela, a cor branca da montaria representa a página em branco da vida do vaqueiro, logo após a perda da família que tinha. Além disso, Orminda, uma cabocla filha do 
Coronel, não era negra ou com traços indígenas como as demais, inclusive Alaíde; Orminda tinha a pele clara, daí também a presença da montaria na cor branca do Ramiro, que passou boa parte do tempo narrativo com a personagem da filha do fazendeiro.

Os "podres dos brancos" era que tocava fundo no povo e enfurecia os brancos. Assim como a temática das chulas do Ramiro eram as de Almiro Ferreira, vaqueiro real na memória de Feio Junior (2004, p. 161):

\begin{abstract}
Dentre tantos vaqueiros poetas e humoristas que transformavam em música e verso a história dos mais variados acontecimentos, não podemos deixar de citar Almiro Ferreira, que criou fama na região do Ararí por sua sátira, veia poética e humor. Homem forte de físico avantajado, sempre alegre e sorridente, contagiou com suas modinhas, suas chulas, suas poesias que descreviam nitidamente os fatos que davam origem a suas criações, com humor, simetria poética, narrativa e musical, cronologia e tonalidade. Não escondia nem figurava os personagens envolvidos e os identificava pelos seus próprios nomes.
\end{abstract}

Missunga encontra Ramiro e Orminda e, pelo monólogo e pela perspectiva figural, o narrador transmite o que o filho do fazendeiro pensa: "Missunga encarou Ramiro lembrandose do ato de Manuel Raimundo que o expulsava das fazendas e ao recordar a cantiga do vaqueiro ferrado, teve uma rapidíssima impressão, não totalmente lúcida, de que o instrumento do castigo, de que se servira o pai, não fora a marca em fogo mas a própria inércia do filho" (JURANDIR, 2016, p.233). Também, ele não confessa o que está pensando:

\begin{abstract}
Missunga viu no olhar de Orminda qualquer coisa de uma acusação, o obrigava a confessar-se a si mesmo, como culpado também. Ambos estavam vexados. Orminda, pela condição de mulher de beirada, o rosto marcado, andando à toa. Missunga porque não a pegava pelo braço e não a levava dali. Se lhe dissesse, mesmo sem certeza: - Sabes, Orminda, que sou teu irmão? ela recuaria espantada. Seria talvez pior ao vê-la confusa, abatida, fugindo-lhe, como uma culpada (Ibid.)
\end{abstract}

De repente, Orminda, pensa na sua mãe velha que "estava doente e sem ninguém em Ponta de Pedras" (Ibid. p. 234). Seu companheiro, já antes, sentia que ela vai partir, "os cabelos soltaram-se e ela os apanhou cruzando as mãos sobre a nuca. Ramiro fitou-a com surpresa e teve, como nunca, um pressentimento de que em breve ela, sem uma palavra, o deixara" (Ibid.). Após a morte de Gaçaba, Ramiro é suspenso e foi para outra fazenda. Um inverno inteiro se passa até que Ramiro retorne da Diamantina (capítulo 51).

A partir daqui as referências à Orminda são todas em rememorações do vaqueiro que, através de monólogos interiores, mostra ainda toda a influência que a convivência com ela exerce em suas canções. Como não podia ficar na região do Arari, Ramiro retorna rumo à Santa Cruz. Durante todo o percurso muitas lembranças de Orminda são apresentadas. É possível de saber que, a certa altura, o vaqueiro tem ciência do aleive que há contra a companheira em Cachoeira e decide fazer uma chula para defendê-la.

\footnotetext{
Agora era tirar com sentimento uma chula para Orminda, defendendo a próxima do aleive da torre. Por mais que fosse certo, era preciso defendê-la, era do sentimento da chula fazê-la inocente. [...] Teria de cantar, junto dela, no escuro para não se encabular, a chula que havia de a defender" (Ibid., p. 306-307).
}

Percebemos que a ideia das canções é para defender de qualquer injustiça. Desta vez, o objetivo é ir contra o aleive inventado de que Ormida havia se deitado na torre da igreja com o Sacristão, e por conta disto, seu corpo teria ficado marcado no assoalho da torre: "era do sentimento da chula fazê-la inocente." Enquanto rememora e cavalga, Ramiro soube, por um companheiro, da proibição da pesca imposta pelo administrador aos moradores das margens do rio onde nascera. O narrador, por um monólogo interior de Ramiro, indica: 


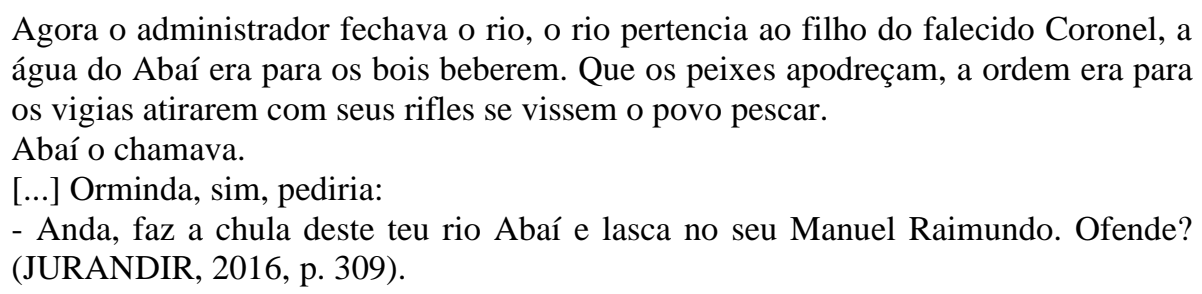

Claramente, vemos a influência que Orminda, mesmo ausente, exerce sobre as composições do vaqueiro contra as injustiças nas fazendas. Vê-se também que Orminda "pediria". Primeiro, o tempo verbal indica o pensar do Ramiro nela, Orminda não está mais com ele, mas ela o incentiva; a companheira sempre, com jeito, conseguiu que o vaqueiro compusesse suas músicas de revolta. Ainda, através de um monólogo interior, indica o que o povo poderia fazer de forma organizada. Ademais, com conjecturas, aponta o que Orminda diria. Na verdade, Ramiro apresenta o discurso de Orminda, não dele:

Ramiro sentia que aquele povo podia se reunir, se ajuntar num só homem e abrir o rio. Povo desunido e com medo era como peixe apodrecendo num rio fechado. Era assim que Orminda diria, era assim que ele diria ao seu povo. Se Orminda estivesse ao seu lado, eram dois que partiriam (Ibid. p. 310).

Sem Orminda, Ramiro retoma seu discurso. Sua personalidade, desde o início, era de revolta contra a injustiça, mas também de divertir o povo com seus cantos: "Disse sem raiva". Depois de beber com dois companheiros vaqueiros, decidiu seus próximos passos:

\footnotetext{
Ramiro saltou, fumaçando, a postema era um veludo, o coração tinha saído como balão atrás de Orminda. Saltou fumaçando:

- Esse Manuel Raimundo eu mato.

Disse sem raiva, tudo lhe saía doce da boca e quis cantar uma chula contra a proibição do Arcebispo (Ibid. p. 311)
}

Algumas informações no discurso do narrador que estão no trecho acima devem ser assinaladas: Primeiro, o contraste de como inicia e termina a fala, intercalando com um discurso do Ramiro. O narrador inicia dizendo: "saltou fumaçando". Saltar fumaçando é saltar com muita raiva, ao pensar que as pessoas, parentes, tios estão passando fome sem peixe, a beira de um rio que tem tanto peixe que estão apodrecendo. No final indica que Ramiro, ao dizer que mata Manuel Raimundo, o diz sem raiva, com doçura. Ainda lembra que Ramiro quis cantar uma chula contra a proibição do Arcebispo. Este último trecho, refere-se ao recolhimento da coroa do Divino determinada pelo Arcebispo. Tirando, como bem disse Ramiro, até a fé do povo. Aflorando assim, mais uma vez, o espírito de resistência do cantor. O trecho salienta também a saudade do vaqueiro com Orminda, além de total do rompimento do cantor com a moça: "o coração tinha saído como balão atrás de Orminda".

Durante, ainda, a bebedeira com os amigos vaqueiros, o imaginário está aberto, não apenas de Ramiro, mas também dos outros dois homens que bebiam com ele, que representa, na verdade, todo o povo pobre das fazendas:

Aquelas três bocas buscavam no fundo do garrafão: Abaís abertos a todos os pescadores, Gaçaba em cima da porteira bebendo tipuca, quartos de carne sabrecando em grossos espetos na fogueira do curral, mulheres parindo nas esteiras bem forradas e travesseiros, carne de graça quando prenhas desejassem [...] foliões do Divino rezando ladainhas sem a lei do Arcebispo. Orminda se embalando numa grande rede sobre o Abaí, barqueiros descarregando peças de pano e baeta, farinha, muita farinha. Viam Manuel Raimundo num tacho de fogo e o Diabo com uma colher de ferro mexendo o caldeirão (Ibid. p. 310-311). 
Tudo o que desejara era o mínimo para que seu povo pudesse viver com dignidade. Era comida, era carne às mulheres grávidas sem que ninguém fosse ferrado em brasa por conta disto. Eram as rezas em ladainhas sem proibições e por fim, o administrador, pior até que os próprios patrões, queimando num caldeirão. Sem mais lembranças de Orminda, sozinho, desde que perdera a mulher e os filhos, o vaqueiro-cantor parte:

De madrugada, na lama, batido, ensanguentado e roto, Ramiro saltou para o campo. Mudou de roupa na sua barraca. Furtou um cavalo, selado. Tirou uma boia da feitoria, amarrou o violão e o cavaquinho na cilha. O cavalo era castanho, afoito, com marca dos Coutinhos.

Olhou o céu e se descobriu como diante de uma imagem. Pediu a proteção do Divino. Adeus, Nhá Diniquinha.

- Vamos ver, Castanho, se tu não me deixar no Abaí, te sangro só no vazio. (JURANDIR, 2016, p. 312).

O cavalo cardão dele, símbolo do recomeço após perder tudo e, também, da companhia de Orminda, se perdera no tempo da narrativa. Já não é mais um cavalo branco, não tem mais a companheira. Quando Ramiro sangrava as vacas gordas, como vingança, ele não tinha sangue para as aventuras dos ladrões, aqui, no entanto, ele furta um cavalo com a marca dos Coutinhos. É a sua nova forma de resistência. Ele está voltando para o Abaí que está fechado com seguranças armados guardando o rio, o que ele vai fazer? O narrador indica que furtar os peixes, como fez com o Castanho, pode ser uma possibilidade, já que ele próprio indicou que o povo não vai se unir porque têm medo.

A viagem é longa. Este fato está indicado quando Ramiro "tira uma boia da feitoria". "Boia" é a forma como pescadores chamam para comida. Ramiro, ainda criança no Abaí, era pescador: "foi ali que viu, pela primeira vez, era ainda bem molequinho, fedendo a peixe, um cavalo e um boi de montaria" (Ibid. p. 308). Sendo assim, é preciso levar comida. Outro apontamento feito que indica que a viagem vai ser demorada é: "“- vamos ver, Castanho, se tu não me deixar no Abaí, te sangro só no vazio". O vaqueiro está desconfiando que, talvez, o cavalo não consiga chegar ao destino final, pela distância. No entanto, ao leitor é cristalino perceber que a montaria do vaqueiro vai chegar, pois o "castanho é afoito", o que significa dizer que tem propensão a ser corredor, resistente, bastando apenas soltar um pouco a rédea.

E por fim, o vaqueiro dá "Adeus", o que representa um final, que não tem mais volta. Pede a proteção do Divino, já que a tarefa é árdua e monta um cavalo Castanho, escrito com letra maiúscula. A cor castanha de um animal é a cor avermelhada. Vermelho, por sua vez, é a cor do sangue, do sangue das vacas que esfaqueava e as deixava sangrando até a morte nos encobertos, e do sangue para aventuras de ladrão que não tinha. Vermelho também remete a conflitos e guerras. Pode ser entendido, além disso, como a cor do fogo que tem o poder de transformação.

Ramiro nasceu no rio Abaí, próximo do município de Cachoeira do Arari, onde o Coronel tem a maior parte das fazendas, aprendeu a tocar violão às margens. Trabalhando pelos Coutinhos, soube que o rio estava fechado, por ordem de Manuel Raimundo, o administrador das fazendas, se revolta e compôs uma "chula", uma forma e dança musical folclórica de Portugal, no Brasil já entrelaçada com a música africana. O narrador relembra do tempo e do histórico do vaqueiro:

E foi ali que nasceu, aprendeu a pescar, a tarrafear, a ter conhecimento com peixes e suas manhas, preferir tucunaré, desprezar a traíra, medir o tamanho dos pacus na palma de sua mão [...] nas suas margens aprendeu a tocar violão, fez a primeira serenata (Ibid. p. 309). 


\section{CONCLUSÃO}

Dalcídio Jurandir, ao eleger um vaqueiro com as habilidades de Ramiro para compor uma parte importante do enredo do romance Marajó (1947), estabelece uma relação com o caráter político do próprio autor que, por sua história, sempre se colocou à esquerda do espectro político, fora preso por defender o povo contra injustiças de sua época. Na ficção apresentada, a "prisão" de Ramiro não é atrás de grades, trancafiado. Pelo contrário, é no mundo, porém sem rumo, sem um lugar que pudesse ficar, graças a expulsão imposta pelo administrador das fazendas. Por conta disto ficava vagando de um lugar a outro. O caráter errante de muitas personagens, muito por conta da restrição que a sociedade dos Coronéis no interior caracteriza, marca e junta Orminda ao Ramiro, por uma temporada, e deixou-o "sem se despedir, a louca Orminda", como repetiu muitas vezes o vaqueiro.

Pelo "discurso vivenciado" do narrador e pela perspectiva figural, Dalcído Jurandir consegue transmitir os pensamentos e sentimentos das personagens, por exemplo, Orminda sentiria verdadeiramente algo por alguém ou mesmo pelo Ramiro? "- Ramiro, meu preto, tenho que passar esta noite com a velha [a mãe do Gaçaba morto]" (JURANDIR, 2016, p. 234). "Gostaria de Ramiro?" se questiona e continua, "gostaria algum dia verdadeiramente de um homem?" (Ibid.).

Por fim, a música folclórica traz o caráter do divertimento, do descanso depois de um dia de trabalho, mas também traz o caráter político das letras das chulas compostas. Lembremos que o surgimento, a origem destas canções é com mulheres negras, escravas que cantam e dançam em devoção aos Santos, o que ficou conhecido como "Taieiras" ou "Talheiras", porque era em talhas que as mulheres traziam água do rio até a casa de seus patrões. As músicas, como forma de culto, serviram no início para agradar a igreja católica. No romance, os vaqueiros e demais caboclos cantam as folias aos santos: Santo Ivo, a Coroa do Divino, São Sebastiao etc. Ramiro era caboclo, descendente dessas mulheres, deu outra conotação as chulas, usou-as como forma de falar, pela língua do povo, "os pobres dos brancos", por influência de sua companheira Orminda. O vaqueiro-poeta-cantor Ramiro com sua música representa os homens e mulheres dos trabalhos duros dos campos, lagos e rios do Marajó, de Dalcídio Jurandir.

\section{REFERÊNCIAS}

AUBERT, Eduardo Henrik. A música do ponto de vista do nativo: um ensaio bibliográfico. Revista de Antropologia, São Paulo, USP, 2007, v. 50 nº 1.

GOMES, Mariana Andrade \& LEMOS, Renato de Lyra. O papel da música na construção da identidade. Intersemiose. Revista Digital. Ano III, n. 05. Jan/jun 2014.

JURANDIR, Dalcídio. Alguns aspectos da Ilha de Marajó. In: Cultura Política. Rio de Janeiro, ano 2, n. 14, 16, 1942.

JURANDIR, Dalcídio. Marajó. Belém: Marques 2016 [1947].

NETTL, Bruno. O estudo comparativo da mudança musical: Estudos de caso de quatro culturas. Revista Anthropológicas, ano 10, vol. 17(1), 2006.

PACHECO, Agenor Sarraf. Cosmologias afroindígenas na amazônia marajoara. Projeto História, São Paulo, n. 44, pp. 197-226, jun. 2012. 
PERCILIA, Eliane. Brasil Escola, c2021. Música de protesto. Disponível em: https://brasilescola.uol.com.br/artes/musica-protesto.htm. Acesso em: 05 jun. 2021.

PLATÃO. Fedro. Trad. José Cavalcante de Souza. São Paulo: Editora 342016 [-370] (Edição bilíngue).

PLATÃO. Fedro. Trad. Pietro Nassetti. São Paulo: Martin Claret 2001 [-370] (Texto Integral).

SALLES, Vicente. A música e o tempo no Grão-Pará (1º volume, 1980).

SALLES, Vicente. Chão de Dalcídio. In: DALCÍDIO, Jurandir. Marajó. Belém: CEJUP 1992 (3 ${ }^{\mathrm{a}}$ ed.), pp 367-381 (texto original de 1978). Reeditado, em 1998, na revista Asas da Palavra (Belém) No. 4 e In: Rosa Assis (Org.). Estudos Comemorativos: Marajó Dalcídio Jurandir 60 Anos. D. Belém: UNAMA 2007, p. 15-30.

SALLES, Vicente. Narrador: Dalcídio Jurandir. VII Jornada do Conto Popular Paraense. Brasília: MicroEdição do Autor 2001 (Vicente Salles, 34).

SALLES, Vicente. Modinha no Grão-Pará: estudos sobre a ambientação e (re)criação da Modinha no Grão-Pará". (Transcrições musicais por Marena Isdebsky Salles. Belém: Secult/IAP/AATB, 2005).

SALLES, Vicente. Repente \& Cordel. Literatura Popular em versos na Amazônia. "Prêmio Silva Romero 1981". Rio de Janeiro: Funarte/Instituto nacional de Folclore 1985.

SIGNIFICADO DOS NOMES. Dicionário de Nomes Próprios, c2021. Sobre significado de nomes próprios. Disponível em: https://www.dicionariodenomesproprios.com.br/ramires. Acesso em: 12 mar. 2021.

SCHMID, Wolfgang. Narratology: an introduction. Berlin/New York: Gruyter, 2010.

SOUSA, Herculano Inglês de. Voluntário. In: Contos Amazônicos. Belém: EDUFPA 2005, p. $29-44$. 